\title{
The association between the quality of life and depression of elderly in a nursing home institutional setting
}

L'ubica Ilievová1* ${ }^{\text {, Peter Žitný2 }}$, Jana Jakobejová1,3

'Department of Nursing, Faculty of Health and Social Work, University of Trnava, Trnava, Slovakia, ${ }^{2}$ Department of Psychology, Faculty of Arts, University of Trnava, Trnava, Slovakia, 3Zariadenie pre seniorov Juraja Schoppera, Rožňava, Slovakia

\begin{abstract}
Introduction: The quality of life is perceived individually and subjectively. The quality of life of elderly people in nursing home nursing homes depends on the degree to which their needs are fulfilled. The need to adapt to a new environment in an older age is a risky situation and may result in depression. The aim of the study was to analyze the change of quality of life and level of depression, as well as possible association of quality of life and level of depression, in elderly people admitted for the first time to nursing home.

Methods: The research included 38 participants (10 men and 28 women). The data were obtained using the Geriatric Depression Rating Scale Short Form (GDS-SF) and a short form of the Quality of Life Enjoyment and Satisfaction Questionnaire (Q-LES-Q-SF).
\end{abstract}

Results: The average age was $79.2(S D=6.9)$ with a variation span of 30 years, minimum age was 62 $(n=1)$ and maximum age was 92 years $(n=1)$. The participants experienced a clinically significant reduction in depression symptoms, moving from a mild depression zone (8-12 points) to the zone of clinical standard (7 points or less). An essential finding was a strong negative correlation between the quality of life and depression.

Conclusions: Obtaining information on depression and the quality of life of elderly in nursing home settings should be introduced as a standard part of nursing activities in order to improve the quality of customer care in the nursing homes.

Keywords: Quality of life; depression; social needs; elderly people; institutional care; nursing home; elderly home

\footnotetext{
*Corresponding author: Lubica llievová,

Department of Nursing, Faculty of Health and Social Work, University of Trnava, Univerzitné námestie 1, 91843 Trnava, Slovakia. Phone: + 421905661024 .

E-mail: lubica.ilievova@truni.sk
}

Submitted: 24 August 2016/Accepted: 15 November 2016 DOI: http://dx.doi.org/10.17532/jhsci.2016.364

UNIVERSITY OF SARAJEVO FACULTY OF HEALTH STUDIES

\section{INTRODUCTION}

The quality of life is perceived and defined in terms of life and mental satisfaction, physical health, and happiness. In defining the quality of life, it is essential to take into account the hierarchy of values of an individual, and his or her satisfaction with the achievement of the objectives that determine the 
direction of his/her life (1). Age is one of the factors associated with the feeling of fulfilment and perception about the meaning and direction of life. Elderly people can perceive their placement into a nursing home setting as a signal of the approaching end of life, which causes stress. Elderly people perceive this change as a loss of their current status that is impossible to maintain. The most common mental illnesses in elderly people is depression. Depression in the elderly is an underestimated, often overlooked, and untreated condition. It negatively affects the course of somatic diseases and can cause impaired self-reliance and cooperation in an elderly person (2). According to the study of Hsu and Wright (3), depression affects $1-5 \%$ of elderly people and it increases a series of negative consequences, such as an increased risk of morbidity and mortality (3). If elderly people reside in an institutional facility for elderly, the degree of fulfillment of his or her needs is naturally related to the quality of care. On the other hand, impaired self-sufficiency and cooperation are also interconnected with the quality of care provided in a facility in which elderly are clients, and thus the reduction of depression symptoms in elderly should be the primary aim in health care of these patients. Good quality care in nursing homes should result in the reduction of depression level in elderly and thus lead to an increase in their cooperation with the facility staff, but also improve their quality of life. The aim of the study was to analyze the change of quality of life and level of depression, as well as possible association of quality of life and level of depression, in elderly, during their first 11-month stay in a nursing home.

\section{METHODS}

The research was conducted in a nursing home "Institution for elderly of Juraj Schopper" in Roznava, Slovakia from May 2014 to March 2015. All the participants in the study were newly admitted to nursing home. Participants had no any comorbidities which could influence their quality of life. During the three months of recruitment all the elderly people consecutively admitted to nursing home were offered participation into the study. The inclusion criteria were: Lucid mental status defined by the score of more than 20 points in the Standardized Mini-Mental State Examination
(SMMSE) and a consent to participate in the research. Elderly diagnosed with dementia or neurologic or psychiatric diseases were excluded. Based on the selection criteria, 38 out of 67 newly admitted elderly were included in the study (56\%).

The research strategy was based on repeated surveys of the quality of life of elderly and depression during their stay in the nursing home. The average number of days spent in the nursing home at the moment of creating the research group was 52 days. The first data collection was carried out in May 2014. Other data collections were carried out each two months. The last, sixth, data collection was carried out in March 2015. In our differentiation-correlational research, exploratory and confirmatory approaches are overlapping (4).

\section{Research methodology}

The participants filled the questionnaires in the presence of researcher, who was available to assist them in case of any doubts or unclearness. The administration of questionnaires and data collection were always carried out by the same person. The conditions were the same for all participants, i.e., the interval of administration of questionnaires was from 10:00 to 12:00. For each participant, privacy and peace were ensured while filling in the questionnaires (5). The procedure consisted of two parts. In the first part, a participant was given a standardized test of mental functions (SMMSE). Subsequently, after meeting the selection criteria (i.e., more than 20 points on SMMSE), the informed consent was obtained. Then, two standardized questionnaires were distributed: Geriatric Depression Rating Scale - Short Form (GDS-SF) and a short form of the Quality of Life Enjoyment and Satisfaction questionnaire (Q-LES-Q-SF). The standardized test of mental functions is characterized as a valid and reliable tool for assessing cognitive functions in elderly people. The reliability of the Mini-Mental State Examination (MMSE) varies from 0.68 to 0.96 , specificity from 0.78 to 1 , and the sensitivity from 0.75 to 1 (6). In this study, we used one of the versions of MMSE (7). MMSE was modified by Molloy et al. (8) with the aim to reduce the variability of a final score which is caused by an improper administration (8). The Slovak translation of this tool mentions several names of MMSE, 
e.g., test by Folstein, Folstein's test, and Mini test of mental state. The Slovak version of SMMS was published by Vajdičková and Kolibáš (9). The final score of 24-30 is considered normal; 20-23 is rated as mild cognitive impairment, $10-19$ as medium cognitive impairment, and $0-9$ as severe cognitive impairment.

We used GDS-SF to measure the depression which is characterized as a factor that affects the cognitive function of elderly (10). GDS-SF was modified by Sheik and Yesavage based on the long version of GDS, which consists of 30 items and was reported as a valid and reliable self-evaluation tool, with the sensitivity of 0.92 and specificity of 0.89 (11). A high correlation was confirmed between the two versions of the questionnaire (12). The GDS-SF includes 15 items, it is easier to use this version for physically disabled, tired elderly people, and those with mild to moderate dementia. The tool can also be used in patients with dementia when they are able to understand and answer the questions (13). In the Slovak version of the tool, the final score of 0-7 points is considered to be normal, $8-12$ points is considered as mild depression, and 13-15 points as heavy depression (14).

The Q-LES-Q-SF is a self-evaluation questionnaire consisting of 16 items abstracted from the original scale of 93 items (15). It maps the overall quality of life, satisfaction with physical health, mood, work, leisure, social and family relations, economic status, overall well-being, as well as the satisfaction with health care. Participants record their answers on a 5-point Likert-type scale, ranging from very dissatisfied to very satisfy.

\section{Statistical analysis}

Friedman test for $k$ dependent samples was carried out. The nonparametric Wilcoxon signed rank test for dependent samples was used for the identification of significant changes in the level of quality of life and depression among the participants, between six repeated measurements during their stay in the nursing home. Spearman's rank correlation coefficient was used for testing the correlation between quality of life and level of depression. Descriptive statistics (average, standard deviation, median, minimum and maximum values, and the values of the first and third quartile) of the quality of life and depression, in each of the six measurements, were determined from the collected data.

\section{RESULTS}

There were 10 men (26\%) and 28 women (74\%). The average age was $79.2(\mathrm{sd}=6.9)$ with a variation span of 30 years; minimum age was $64(n=1)$ and maximum age was 92 years $(\mathrm{n}=1)$. The average age among the male participants was $78.4(\mathrm{sd}=9.9)$ and among women $79.5(\mathrm{sd}=5.8)$. Regarding the marital status, 24/38 (63\%) participants were widowed, $3 / 38$ (8\%) were divorced, 4/38 (11\%) were married, and 7/38 (18\%) did not provide the information on their marital status.

The changes in the level of quality of life of participants during their 11-month stay in the nursing home were analyzed with the Friedman test of variance for $k$ dependent samples. The results showed statistically significant differences between individual measurements of the quality of life of participants in the nursing home $\chi^{2}(5)=46,463 ; p=0.000(\mathrm{n}=38)$. To test the differences between the first and the last (sixth) measurement of the quality of life of participants, the nonparametric Wilcoxon signed rank test for dependent samples was applied (Table 1). The results showed that the quality of life of participants between the first (median $=41.5$ ) and the last measurement (median $=46.0)$ was statistically, significantly different; $Z=-4.065 ; p=0.000$ (Figure 1). The changes in the level of depression in participants during their 11-month stay in in the nursing home were tested using the Friedman test of variance for $k$ dependent samples. The results showed statistically significant differences between individual measurements of depression levels in participants during their stay in the nursing home $\chi^{2}(5)=15,917 ; p=0.007(\mathrm{n}=38)$. The nonparametric Wilcoxon signed rank test for dependent samples was used to test the differences between the first and sixth measurement (Table 2). The results demonstrated that the level of depression in participants between the first (median $=8.5)$ and the sixth measurement (median $=6.0$ ) was statistically, significantly different; $Z=-1.493 ; p=0.038$ (Figure 2). The overall average level of depression in participants during their 11-month stay in the nursing home showed a very strong negative correlation and a significant relationship with their overall average quality of life $[r=-0.82]$ (Figure 3 ). 
TABLE 1. The quality of life of elderlies measured by Wilcoxon signed-rank test ( $1^{\text {st }}$ measurement versus $6^{\text {th }}$ measurement)

\begin{tabular}{lccccc}
\hline Order & $\mathrm{n}=38$ & Average order & Sum of orders & $Z$ & Exact significance \\
\hline Negative orders & 8 & 10.31 & 82.50 & -4.065 & 0.000 \\
Positive orders & 29 & 21.40 & 620.50 & & \\
Identical orders & 1 & & & & \\
\hline
\end{tabular}

Two-way test of significance

TABLE 2. Depression in elderlies measured by Wilcoxon signed-rank test ( $1^{\text {st }}$ measurement versus $6^{\text {th }}$ measurement)

\begin{tabular}{lccccc}
\hline Order & $\mathrm{n}=38$ & Average order & Sum of orders & $Z$ & Exact significance \\
\hline Negative orders & 22 & 20.45 & 450.0 & -1.493 & 0.038 \\
Positive orders & 15 & 16.87 & 253.0 & & \\
Identical orders & 1 & & & & \\
\hline
\end{tabular}

Two-way test of significance

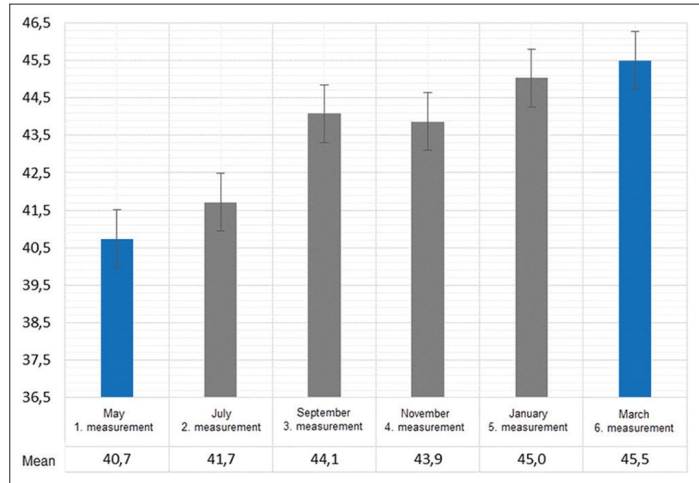

FIGURE 1. The quality of life of elderly people measured by Wilcoxon signed-rank test $\left(1^{\text {st }}\right.$ measurement versus $6^{\text {th }}$ measurement).

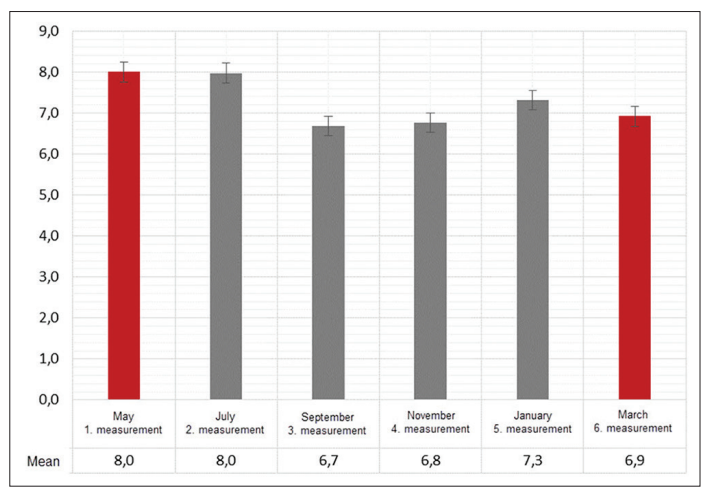

FIGURE 2. Depression in elderly people presented as a difference between the $1^{\text {st }}$ and $6^{\text {th }}$ measurement.

\section{DISCUSSION}

Based on our results we can conclude that in general, the quality of life of the elderly during their 11-month stay in the nursing home, determined between the first and last measurement, showed a statistically significant increase in the quality of life, i.e. 8 participants showed a lower level of the quality of life in the last measurement (in March 2015) compared with the first measurement (in May 2014), while 29 participants showed a higher level of the quality of life in the last measurement. In one participant, no difference in the quality of life between the first and last measurement during the period of 11 months was observed. Based on these results, it might be reasonable to expect that the first months in the nursing home are related to a difficult process of adaptation of elderly to the new environment, associated with a change in the existing habits and way of life, which can probably cause an increased inner tension, insecurity, fear, and anxiety. Furthermore, depression symptoms in this period are either unchanged or accentuated, as a daily life in an nursing home is characterized by specific organization and adherence to the existing rules. Dealing with the new situation can be difficult for elderly people, due to their weakened adaptive mechanisms which naturally comes with age, but also due to adherence to certain stereotypes that are associated with their previous way of life (16). The placement in a nursing home is also associated with the need to give up, at least a part, of their autonomy. The organization and comfort in the nursing home, provided by the personnel, can reduce the motivation of elderly to perform various activities that once used to be a part of their daily life. In a Norwegian study conducted by Drageset et al. (17), 


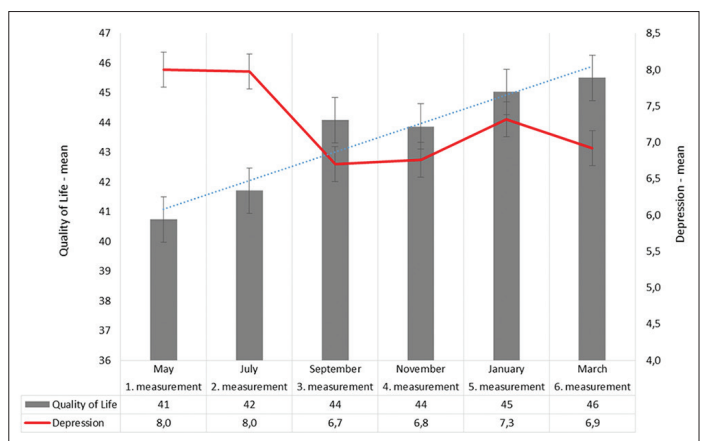

FIGURE 3. Graphical representation of a relationship between the quality of life and depression in elderlies.

which identified the relationship between social support, integrity and quality of health and life of elderlies in nursing homes, it was revealed that the relationship between elderly and social environment play an important role in their mental health (17). Our findings showed that the level of depression in elderly, between the first and last measurement during their 11-month stay in the nursing home, was significantly decreased. In 22 participants, a lower level of depression was observed during the sixth measurement (in March 2015) compared with the first measurement (in May 2014). Fifteen participants showed higher levels of depression, and, only in one participant, there was no difference between the two measurements. The overall level of depression in participants during their 11-month stay in the nursing home showed a very strong negative correlation and significant relationship with the overall level of the quality of life. When elderly become a part of an institution, the loss of identity and individuality in these people is a common problem in social care, and it is often manifested by symptoms of depression. This is due to an inappropriate, unprofessional, and impersonal way of care in institutional care facilities (18). Depression is one of the most common mental illnesses of old age. In developing depression, genetic, biological and psychosocial factors play an important role. A relation between depression and age, female gender, feeling of loneliness and psychosocial factors are confirmed by other studies as well (19-21). Our findings showed that after getting through the natural period of adaptation to the new environment, a significant increase in the quality of life was observed during the second measurement, as well as a significant reduction in depression symptoms. However, in the following next months, there was no statistically significant increase in the quality of life. We assume that this gradual increase is related, to some extent, to the gradual fulfillment of the elderly needs. Depression showed the same dynamics of change. Between the third and fourth month following the institutional stay, there is a substantial decrease in depression symptoms in the elderly. The most important finding is that a clinically significant reduction in the depression symptoms occurred in the elderly, moving from a mild depression zone (8-12 points) to a clinical standard zone (7 points or less). An interesting and significant finding is a very strong negative correlation between the quality of life and depression. Previously, it has been shown that a higher quality of life of elderlies in a nursing home is associated with lower levels of depression. Although we cannot completely explain the causality and underlying mechanisms of the observed differences and correlations, our results represent an important first step in this research area.

\section{CONCLUSION}

We investigated quality of life and level of depression changes in elderlies during their first 11-months stay in a nursing home. We found, that their quality of life increased and that the level of depression significantly decreased during their stay in nursing home. We analyzed correlation between the quality of life and depression of elderlies in nursing home. The overall level of depression showed a negative correlation and was significantly related to the quality of life. The results of our study should be further confirmed in a larger setting and may be applied the field of nursing research and practice, to improve psychosocial adaptation and the quality of life of the elderly people in nursing homes.

\section{CONFLICT OF INTEREST}

The authors declare no conflict of interest.

\section{REFERENCES}

1. Hrozenská M. Sociálna práca so staršími l'ud'mi a jej teoreticko-praktické východiská. Martin: Osveta; 2008.

2. Holmerová I, Vaňková H, Jurašková B. Deprese ve stáři. Lékařské listy. Bratislava. 2007;12(56):6-8. 
3. Hsu YC, Wright $\mathrm{CL}$. The association between participation in social activity and depressive symptoms in institutionalized elders in Taiwan. Geriatr Nurs 2014;35(1):31-6.

https://doi.org/10.1016/j.gerinurse.2013.09.004.

4. Ferjenčik J, Bakalář P. Úvod do metodologie psychologického výzkumu: Jak zkoumat lidskou duši. Praha: Portál; 2010.

5. Kutnohorská J. Výzkum v ošetřovatelství. $1^{\text {st }}$ edition. Praha: Grada; 2009.

6. McDowell I. Measuring Health: A guide to rating scales and questionnaires. $1^{\text {st }}$ edition. Oxford New York: Oxford University Press, Inc; 2009.

7. Folstein MF, Folstein SE, McHugh PR. "Mini-Mental State". A practical method for grading the cognitive state of patients for the clinician. J Psychiatr Res 1975;12(3):189-98.

https://doi.org/10.1016/0022-3956(75)90026-6.

8. Molloy DW, Standish TI, Lewis DL. Screening for mild cognitive impairment: Comparing the SMMSE and the ABCS. Can J Psychiatry 2005;50(1):52-8.

9. Vajdičková $K$, Kolibáš $E$. Príručka $k$ administrácii štandardizovaného MMSE. Bratislava: Pfizer. [Online]. 2008 [Cited 2014 Febr 2]. Available from: http://www.Alzheimer.Sk/Download/Pfizerblok.Pdf>.

10. Jirák R. Deprese u seniorů - biologické a psychosociálni vlivy, vztahy deprese a demence. Psychiatria pre Prax. 2007;8(5):200-4.

11. Kurlowicz LH. Nursing standard of practice protocol: Depression in elderly patients. NICHE faculty. Geriatr Nurs 1997;18(5):192-9. https://doi.org/10.1016/S0197-4572(97)90092-6.

12. Marc LG, Raue PJ, Bruce ML. Screening performance of the 15 -item geriatric depression scale in a diverse elderly home care population. Am J Geriatr Psychiatry 2008;16(11):914-21.

https://doi.org/10.1097/JGP.0b013e318186bd67.
13. Fortinash KM, Holoday-Worret PA. Psychiatric mental health nursing: Instructor's resource manual. London: Mosby; 2009.

14. Németh $F$, Babčák $M$, Eliašová, $A$. Skríningové vyšetrenie depresie $u$ seniorskej populácie Prešovského kraja. Geriatria. 2007;13(4):150-5.

15. Endicott J, Nee J, Harrison W, Blumenthal R. Quality of life enjoyment and satisfaction questionnaire: A new measure. Psychopharmacol Bull 1993;29(2):321-6.

16. Hegyi L. Zlyhanie adaptácie vo vyššom veku. $1^{\text {st }}$ edition. Bratislava: Asklepios; 1993.

17. Drageset J, Eide GE, Nygaard HA, Bondevik M, Nortvedt MW, Natvig GK. The impact of social support and sense of coherence on health-related quality of life among nursing home residents-A questionnaire survey In Bergen, Norway. Int J Nurs Stud 2009;46(1):66-75. https://doi.org/10.1016/j.jinurstu.2008.07.005.

18. Krajčík Š, Štefko A. Etické problémy v geriatrii. In: Šoltés $L$, Pullmann $R$, et al. Vybrané kapitoly z medicinskej etiky. Martin: Osveta; 2008.

19. Lépine JP, Bouchez S. Epidemiology of depression in the elderly. Int Clin Psychopharmacol 1998;13(Suppl 5):S7-12.

https://doi.org/10.1097/00004850-199809005-00003.

20. Cole MG, Dendukuri N. Risk factors for depression among elderly community subjects: A systematic review and meta-analysis. Am J Psychiatry 2003;160(6):1147-56.

https://doi.org/10.1176/appi.ajp.160.6.1147.

21. Gostynski M, Ajdacic-Gross V, Gutzwiller F, Michel JP, Herrmann F. Depressiona amon tie elderly in Switzerland. Nervenartz 2009;73(9):851-60.

https://doi.org/10.1007/s00115-002-1369-1. 